\title{
PALLIATIVE CARE AS A FORM OF RELIEF FOR THE DYING: A SOUTH AFRICAN PERSPECTIVE
}

\author{
Marc Welgemoed \\ $B$ Juris LLB LLM \\ Admitted Attorney and Lecturer \\ Nelson Mandela University \\ Dr Henry Lerm \\ Dip (Industrial Admin) B Proc LLB LLM LLD \\ Admitted Attorney \\ Research Associate, Nelson Mandela University \\ Director and Chairperson for the Eastern Cape \\ Branch of the South African Medico Legal \\ Association
}

\section{SUMMARY}

This article has a critical look at the current state of affairs in palliative care in South Africa. While euthanasia remains unlawful in South Africa, there is only one alternative - namely, palliative care - to mitigate pain and symptoms, make life tolerable, and ease the emotional stress of dying for patients and their families. Palliative care, unlike euthanasia, has always been regarded as a sound medical practice, ethically, morally and legally. The practice the world over includes family, friends and community. However, no system or legislation has been put in place in South Africa to serve as a guideline for end-of-life practices. The focus of this article is to try to establish guidelines through a multidisciplinary approach that includes the family and makes use of community resources to improve the quality of life of patients and families facing the problems associated with life-threatening illness, through the prevention and relief of suffering.

\section{1}

\section{INTRODUCTION}

Besides the certainty that all human beings will die, there is also a degree of certainty that death is often preceded by intractable and unbearable illnesses, which illnesses can cause immense suffering to both the dying and their loved ones. It is here that palliative care the world over has sought to address not only physical suffering but also the emotional, social and spiritual suffering of people with life-limiting conditions. Generally, palliative 
care refers to the treatment of patients who are in the final stages of their illness and, most probably, their lives. However, palliative-care treatment, in conjunction with other therapies, is also applicable early in the course of a patient's illness. This type of treatment, as well as other applicable therapies, is intended to prolong life. Other applicable therapies include both chemotherapy and radiation therapy.

The object of palliative care is to seek medical relief. This end-of-life care focuses on controlling distressing symptoms and providing emotional and social support, as well as spiritual care in order to assist the patient to live his or her life as actively as possible. ${ }^{2}$ Furthermore, palliative-care specialists assist not only the patients, but also their families in order to determine an appropriate course of treatment. This treatment serves as relief to the dying, as well as providing comfort to the patient's family in the sense that they are aware that the patient is given good care.

A brief glimpse at palliative care from a historical point of view reveals that this type of treatment is not new. The first traces thereof date back many centuries when sick and dying people in primitive communities, through communal rituals, received pain-relief treatment, albeit in rudimentary form. ${ }^{3}$ As communities became more sophisticated, so did the methods of treatment, until the form of palliative practices known today were introduced.

Those practices eventually found their way to South Africa. It is especially the Hospice Palliative Care Association of South Africa (HPCA) that has sought to improve quality of life for patients and their families facing the problems associated with life-threatening illnesses. ${ }^{4}$ The HPCA sets guidelines with regard to palliative treatment. Treatment is provided for, inter alia, cancer, pulmonary disorders, renal disease, HIV/AIDS, progressive neurological conditions and, more recently, children with serious illnesses. ${ }^{5}$ The HPCA guidelines include services that are available to persons of any age suffering from a life-limiting condition, care and support available to patients and their families, as well as referrals for palliative care by a variety of people, including patients themselves, their families, neighbours, friends, doctors or nurses. ${ }^{6}$ Provided that the patient qualifies for palliative care and consents to the treatment, he or she will be enrolled in a palliative-care programme at an institution, like a hospice, and treated by a palliative-care

\footnotetext{
World Health Organisation "WHO Definition of Palliative Care" (2019) https://www. who.int/cancer/palliative/definition/en/ (accessed 2019-05-29).

2 Gwyther "When Should One Start Palliative Care?" 2011 CME: Your South African Journal of CPD: Palliative Care 292; Kirk and Collins "Difference in Quality of Life of Referred Hospital Patients After Hospital Palliative Care Team Intervention" 2006 South African Medical Journal 101101.

3 Gonzalez and Ruiz "The Cultural History of Palliative Care in Primitive Societies: An Integrative Review" http://www.scielo.br/scielo.php?pid=S0080-62342012000400033\&script =sci arttext\&tIng=en (accessed 2020-02-15).

4 Hospice Palliative Care Association of South Africa "Who Qualifies" https://hpca.co.za/ palliative-care/who-qualifies (accessed 2019-05-24).

5 Wikipedia "Palliative Care" https://en.wikipedia.org/wiki/Palliative_care (accessed 2019-0529).

6 World Health Organisation https://www.who.int/cancer/palliative/definition/en/.
} 
nurse. ${ }^{7}$ Palliative practitioners can assist patients with pain and symptom control, psycho-social support and appropriate advice in that regard, spiritual, emotional and bereavement support, as well as the provision of necessary equipment - for example, wheelchairs. ${ }^{8}$

Despite HPCA's noble attempts to promote palliative care in South Africa, this mechanism to care for the ill and to improve their quality of life has not gained much momentum in South Africa. Moreover, assisted suicide, a more contentious issue than palliative care, has attracted greater attention from academic writers and courts alike all around the world. For this reason, there is less debate about the role that a comprehensive palliative and hospice healthcare service can play in assisting terminally ill patients to endure less extreme suffering and accompanying loss of dignity.

Recently, the Supreme Court of Appeal, in Minister of Justice and Correctional Services $v$ Estate Stransham-Ford, ${ }^{9}$ rejected the argument that assisted suicide should be legalised. Instead, the court seemed to hint at introducing the practice of palliative care in assisting end-of-life care. ${ }^{10} \mathrm{~A}$ hallmark of this acceptable medical practice is that it enhances quality of life by managing distressing clinical complications of those with life-threatening illnesses and assists the dying to die in dignity. In this light, the need for a forensic investigation into the worth of palliative and hospice care becomes apparent. This article aims to provide arguments as to why such a mechanism is vital in South Africa given our constitutionally aligned values.

The questions sought to be answered can be formulated as follows:

(a) Would a comprehensive palliative and hospice healthcare service legally help negate end-of-life suffering of the dying?

(b) What exactly are the legal boundaries, if any, within which palliative and hospice-care treatment should operate?

A good way to understand the law in this regard is to look at the origin of palliative and hospice-care treatment, as well as the development of the legal principles regulating it. Furthermore, it is worth investigating the principles relating to palliative care applied in other progressive jurisdictions in order to determine whether the principles applicable in South Africa require reconsideration. In this regard, the legal positions in the Netherlands and Canada are discussed. The Constitution ${ }^{11}$ provides a strong foundation for the direction in which the law relating to palliative care should strive to develop. Section 27 provides:

"(1) Everyone has the right to have access to-

(a) health care services, including reproductive health care;

(b) sufficient food and water; and

(c) social security, including, if they are unable to support themselves and their dependants, appropriate social assistance.

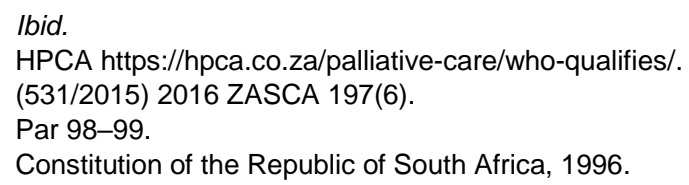


(2) The state must take reasonable legislative and other measures, within its available resources, to achieve the progressive realisation of each of the rights.

(3) No one may be refused emergency medical treatment."

It is argued that palliative-care services are included in the "health care services" referred to in this section. It is also argued that should a patient in need of palliative care not have sufficient funding to provide for such treatment, the State should provide the patient with social security measures in order to access such services. In order to give full effect to this section, it is furthermore also recommended that the government should promulgate legislation, in the very near future, to provide for palliative-care institutions and quality palliative-care services to be instated all over South Africa. ${ }^{12}$ In this regard, the National Health Insurance Bill of 2019 may be a significant start. $^{13}$

\section{HISTORY AND BASIS OF PALLIATIVE CARE}

The term "palliative care" is not a modern concept. It is an idea already known to primitive societies whose communities had to deal with extreme illness and death long before the invention of sophisticated medical practices. The aim then also included the lessening of pain experienced by those who were dying. Tribal rituals and primitive cultures played important roles in this regard.

It was during the rise of paleopathology that humans started experimenting with medicine and commenced proving their knowledge on illnesses. Although this era introduced changed beliefs, the form of palliative care and practices applied were founded in traditional customs. ${ }^{15}$

During the Animist period, the ideal of communitarianism continued. Each person was given a role in their respective cultural groups to promote social cooperation that benefitted the entire human group. It was during times of hardship, and just before the death of a person, that the group would attend to the sick and provide care to the family. This care can be equated to the modern concept of palliative care and promoted solidarity within the family and the group. ${ }^{16}$

The etymology of palliative care emerged from the ancient Roman era. "Care" derives its meaning from the Latin word "cogitare", which implies a concern with the past, present or future problems. ${ }^{17}$ Palliative care and death

\footnotetext{
See heading 62 in this regard.

See heading 32 in this regard.

Kleinman "Indigenous Systems of Healing: Questions for Professional, Folk and Popular Care" in Warren Salmon J (ed) Alternative Medicines, Popular and Policy Perspectives (1984) 138-164; repeated in Gonzalez and Ruiz http://www.scielo.br/scielo.php?pid= S0080-62342012000400033\&script=sci_arttext\&tIng=en; 2012 46(4) Revista da Escola de Enfermagem USP 1015.

15 Gonzales and Ruiz http://www.scielo.br/scielo.php?pid=S0080-62342012000400033\&script =sci_arttext\&tIng=en.
}

16 Ibid.

17 Ibid. 
then were also associated with cases of sick people's extreme suffering as well as those who experienced unbearable pain and despair. ${ }^{18}$ Hippocrates (ca. $460 \mathrm{BC}-370 \mathrm{BC}$ ) stipulated as follows in the original Oath:

"To please no one will I prescribe a deadly drug nor give advice which may cause his death."

That statement served as a clear indicator at the time that euthanasia was not favoured by Hippocrates. What was advocated instead was palliative care. The term "palliative" is derived from the Latin verb "palliare", a concept generally indicating the action of cape or cover. In the care context, palliative action meant a therapeutic action that served to mitigate the problems that diseases cause, without looking to cure them. ${ }^{20}$ What followed was the establishment of codes of ethics and legislation featuring palliative directives, the purpose of which were to bring relief to those dying. To this end, when the health of a patient could no longer be restored, there was an ethical duty on caregivers to alleviate the pain experienced by their patients. ${ }^{21}$ The effect was that a healthcare practitioner had a duty to preserve life through palliative care as a means to take away pain, as well as to ease the last days or weeks of a patient's life. This still seems to be the position in modern times. ${ }^{22}$

The concept of a hospice seems to have developed as an offshoot from palliative care in its most rudimentary form in primitive days and beyond. It evolved over many centuries in Europe with the setting-up of shelters for travellers in around the fourth century AD. ${ }^{23}$ Palliative care, dispensed from the hospices, took a more structured form. The Greeks called these hospices xenodochia or "refuges for the strangers". They became known in Roman times as hospitium, derived from the Latin word hospes or "host". ${ }^{24}$ However, it was especially during the Middle Ages that hospices proliferated. Not only were travellers sheltered, but hospices also served as havens for sick and dying persons. However, for inexplicable reasons, hospices ceased to exist in the sixteenth century, resulting in great human suffering. ${ }^{25}$ However, hospices resurfaced towards the end of the nineteenth century when religious orders re-established them in places like Dublin, Lyons and Sydney. The aim of these hospices was specifically to care for the dying. ${ }^{26}$

This section of the Hippocratic Oath is quoted by the MNT Knowledge Centre "What Is Euthanasia (Assisted Suicide)? What Is the Definition of Assisted Suicide or Euthanasia?" (26 September 2014) http://www.medicalnewstoday.com/articles/182951.php (accessed 2014-12-01).

20 Gonzales and Ruiz http://www.scielo.br/scielo.php?pid=S0080-62342012000400033\&script =sci_arttext\&tIng=en.

21 Mdhluli "Your Life, Your Decision? The Constitution and Euthanasia" June 2017 De Rebus 2526.

22 Dippenaar "Assisted Death and the Law" (10 October 2016) http://www.fin24.com/Money/ Wills-and-trusts/assisted-death-and-the-law-20161010 (accessed 2017-09-29).

23 Devaraj "Palliative Care: A Beginning" 2002 57(4) Med J Malaysia 384-389.
}

24 Ibid.

25 Ibid.

26 Ibid. 
The modern hospice movement was started by the pioneer, Dame Cicely Saunders. ${ }^{27}$ She was a nurse by profession in the St Luke's Hospice in London and worked both as nurse and social worker. She also went on to qualify as a doctor. Combining her compassion with medical skills, in 1967 she started an in-patient service for the sole purpose of bringing relief to the suffering of terminally ill patients and their families. ${ }^{28}$ Two decades later, palliative medicine was first recognised as a speciality in the United Kingdom. ${ }^{29}$

Today, palliative care is viewed as an interdisciplinary approach to specialised medical and nursing care, providing people with relief from pain and suffering. ${ }^{30}$ It is seen as an integrated system, aimed at bringing physical, psychological, emotional and spiritual care to a dying person when cure is not possible. This is in alignment with the World Health Organisation's definition of health being "[a] state of complete physical, mental and social well-being". ${ }^{31}$ Palliative care is also viewed as a method to improve the quality of life of all those affected by a life-threatening illness. ${ }^{32}$ Those who benefit from palliative care include the patient, the patient's family, friends and broader community. ${ }^{33}$ The communitarian attitude and influence of the family and broader community in caring for the patient received the attention of the Supreme Court of Appeal in the Estate Stransham-Ford case. ${ }^{34}$ The court seems to have attached much weight to an affidavit attested to, on behalf of the HPCA, by a palliative-care social worker employed at the Baragwanath Academic Hospital. In her affidavit, the social worker described palliative care in the black communities as "a gift to preserve life". On the question of the legitimacy of assisted suicide, she described it as "alien to the black culture". ${ }^{35}$ The court held that, in addressing these issues, a court needs to give due consideration to the importance of "the notion of a dignified death", which must be informed by a rounded view of society and not confined to a restricted section of it. ${ }^{36}$

Palliative treatment has also been positively appraised in that it can be provided across multiple settings, including in hospitals, homes and skilled nursing facilities. It may also be administered as part of community palliativecare programmes. ${ }^{37}$

It is also worth noting that there is a distinction to be made between palliative care and hospice care. They may have similar goals, inter alia to promote dignity in death, but while a hospice is a concept of holistic care

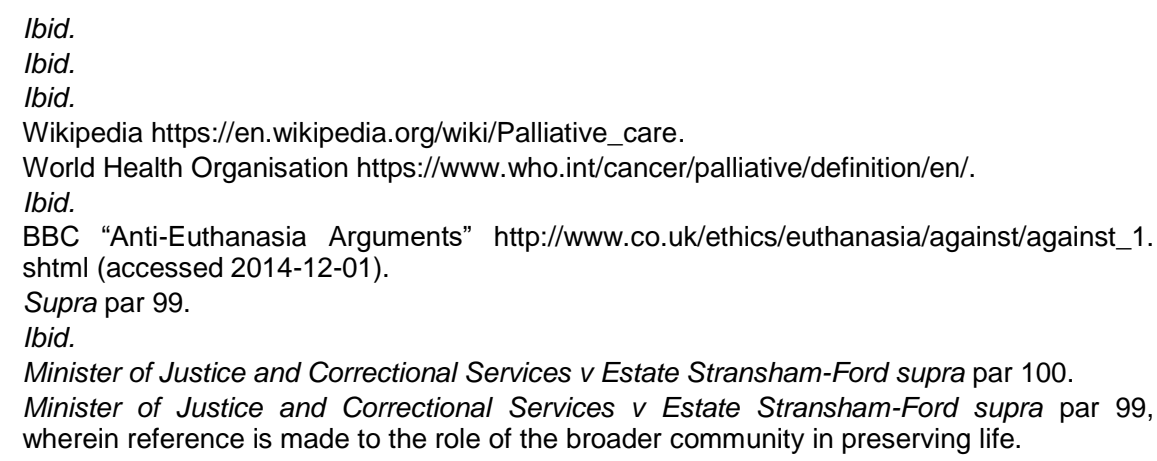


without curative intent, palliative care is intended to bring relief to anyone with a serious, complex illness, whether or not they are expected to recover fully. ${ }^{38}$

\section{PALLIATIVE CARE AND PALLIATIVE SEDATION IN SOUTH AFRICA}

\section{Definition}

The End of Life Decisions Draft Bill ${ }^{39}$ defines palliative care as "treatment and care of a terminally ill patient with the object of relieving physical, emotional and psycho-social suffering and of maintaining personal hygiene". ${ }^{40}$ The HPCA defines palliative care as

"an approach that improves the quality of life of patients and their families facing the problem associated with life-threatening illness, through the prevention and relief of suffering by means of early identification and impeccable assessment and treatment of pain and other problems, physical, psychosocial and spiritual."

The South African Law Commission defines palliative care as "medical intervention not intended to cure but to alleviate suffering, including the emotional suffering, of the patient" ${ }^{42}$ The Commission adds that palliative care "is concerned with the quality of life when, in the course of an illness, death becomes inevitable" and also that "with palliative care some patients can be kept comfortable until the moment of death". ${ }^{43}$ It is submitted that the definition in the Draft Bill is much more descriptive. The World Health Organisation states that palliative care "is applicable early in the diagnosis in conjunction with other therapies that are implemented to prolong life". ${ }^{44}$

\section{The current legal position}

It appears that, over the years, palliative care for the dying has struggled to gain momentum. Greater use has been made of hospice services for those dying of an incurable disease. However, with more and more hospices closing down because of financial instability, the need for palliative services has increased and it will continue to do so in future. The practice of palliative care, unlike euthanasia, has always been regarded as an ethically sound medical practice, in addition to being morally and legally sound. Perhaps the

38 Wikipedia https://en.wikipedia.org/wiki/Palliative_care.

39 This Bill appears in the South African Law Commission Discussion Paper 71 Project 86 "Euthanasia and the Artificial Preservation of Life" (1997).

40 See $\mathrm{s} 1$ of the Bill quoted by Mukheibir "The Implications of the End of Life Decisions Bill for Palliative Caregivers" 1999 Obiter 163.

41 HPCA "Ethical Issues in Palliative Care" www.hpca.co.za/pdf/legalbook/HPCA\%20 Chapter\%203\%20v6.pdf.

42 South African Law Commission Discussion Paper 71 Project 86 "Euthanasia and the Artificial Preservation of Life" par 3.11; Mukheibir 1999 Obiter 163.

43 Ibid.

44 Gwyther 2011 CME: Your South African Journal of CPD: Palliative Care 291. 
reason that palliative care has always been placed on a moral and ethical pedestal is that those engaged in the treatment of their end-of-life care patients generally render high-quality services, including treating the patient and his or her family with the required respect, dignity and compassion. It is equally important for palliative-care practitioners to discuss the patient's wishes with him or her while he or she is still in a condition to have such a discussion. ${ }^{45}$ If, for example, the patient is reassured that, by way of purposeful palliative care, his or her pain and suffering will somewhat be relieved, his or her desire for euthanasia may disappear. ${ }^{46}$ That seems to be the position hinted at by the Supreme Court of Appeal in the StranshamFord case ${ }^{47}$ in which the court suggested that effective palliative care would lead to patients dying in a homely atmosphere surrounded by their families in a dignified and less anxious way.

Palliative-care clinicians and carers, like any other healthcare practitioners in their practices and treatment of their patients, are expected to act within the ethical guidelines prescribed by the South African Health Professions Council. ${ }^{48}$ The Council has also posted on their website ${ }^{49}$ a National Patients' Rights Charter, setting out a right of access to healthcare services, including palliative care, that is "affordable and effective in cases of incurable or terminal illness" and providing for special needs in the case of "patients in pain". The Health Professions Council provides that the core ethical values and standards required of healthcare practitioners in general (including palliative practitioners) include respect for persons, [protecting patients'] best interests or well-being (non-maleficence), beneficence, human rights, autonomy, integrity, tolerance, self-improvement and community. The medical issues and ethical dilemmas that confront palliative-care practitioners in the course and scope of their practice range widely. Accordingly, they need a good understanding of ethical principles when caring for patients. ${ }^{50}$ One category of ethical transgression by palliative-care practitioners could centre around their competence and conduct with patients. A good understanding of medical ethics directs palliative caregivers to continue to respect the patient not only on a physical and emotional level, but also in exercising an appropriate choice when selecting the type of analgesic or opioid. Mohanti ${ }^{51}$ opines that a lack of knowledge and skill in areas such as pain assessment, improper medication and unavailability of morphine sometimes present complex hurdles. It is for these reasons that it

45 Gwyther 2011 CME: Your South African Journal of CPD: Palliative Care 292; HPCA Position Paper on Euthanasia and Assisted Suicide (2001) and reviewed (2015) 4.

46 Saunders Hospice and Palliative Care: An Interdisciplinary Approach (1990) 105; HPCA Position Paper on Euthanasia and Assisted Suicide 5; Carter v Canada (Attorney-General) (2012) BCSC 886189.

47 Minister of Justice and Correctional Services v Estate Stransham-Ford supra par 35, 85 and 88.

48 Gwyther "Ethics and Palliative Care" 2011 29(7) CME Continuing Medical Education 274276; The South African Health Professions Council of South Africa HPCSA General Guidelines for Health Researchers Booklet 132016.

49 http:www.hpscsa.co.za.

50 Gwyther 2011 CME Continuing Medical Education 274; Mohanti "Ethics in Palliative Care" 2009 15(2) Indian Journal of Palliative Care (IJPC) 89-92.

51 lbid. 
is submitted that a palliative caregiver's decisions must have a strong moral and ethical basis, based on the principle that "no one ought to [be harmed] in his life, health, liberty or possessions". ${ }^{52}$ With many palliative patients in an advanced stage of cancer or chronic illnesses like HIV/AIDS, pain has been identified as the dominant symptom. ${ }^{53}$ Because pain can cause a patient a lot of fear or leave him or her feeling withdrawn, emotional and agitated, unrelieved pain may lead to a miserable death and leave the deceased's family devastated and remorseful in grief. ${ }^{54}$ The treatment and relief of pain has been recognised as a core ethical duty in treating those labouring thereunder and faced with discomfort. ${ }^{55}$ For that reason, in most countries, there is now a legal right to pain relief by way of pain assessment and administration of medication, including morphine, which is known to hasten the death process. Consequently, it is ethical to prescribe narcotics and sedatives for intractable pain, even when there is the possibility of terminal sedation. ${ }^{56}$ However, because euthanasia is illegal in South Africa (in that it constitutes murder), ${ }^{57}$ it is clear that palliative practitioners may not engage in any conduct with the primary intention of causing the death of a patient. ${ }^{58}$ They may also administer medication to a patient that will cause him or her to be sleepy, but not to the stage where the patient becomes comatose. ${ }^{59}$

The administration of morphine is viewed by some as hastening the death of those with incurable cancer and other terminal chronic illnesses and borders on the practice of euthanasia. Yet, it has remained both medically and ethically part of the end-of-life regime. However, a compelling argument can be made for the stark difference between euthanasia, which entails the instant termination of life, and an acceptable medical regime that is aimed at pain-and-symptom control, psychological care and end-of-life management. In a case of euthanasia, there is an intervention undertaken with the express intention of ending a person's life in order to relieve intractable suffering. By contrast, with palliative care, the palliative caregiver is purely alleviating the pain and suffering of the patient without the intention required for his or her actions to constitute murder. Theoretically speaking, if a patient dies after a course of morphine has been administered, the palliative caregiver, if prosecuted, is unlikely to be convicted of murder or culpable homicide; he or she neither acted with intent, nor was negligent in causing the death of the patient provided it is shown that the medication administered to the

52 Mohanti 2009 IJPC 91 with reference to Peel "Human Rights and Medical Ethics" 200598 $J$ Soc Med. 171-173.

53 Mohanti 2009 IJPC 90 with reference to Myers and Shetty "Going Beyond Efficacy: Strategies for Cancer Pain Management" 200815 Curr Oncol. S41-9.

54 Mohanti 2009 IJPC 89-92 https://www.ncbi.nlm.nih.gov/pmc/articles/PMC2902121/ (accessed 2019-02-08).

55 Mohanti 2009 IJPC 91 with reference to Fishman "Recognizing Pain Management as a Human Right: A First Step" 2007105 Anesth Analg. 8-9.

56 Ibid.

57 Minister of Justice and Correctional Services v Estate Stransham-Ford supra par 101.

58 Saunders Hospice and Palliative Care 105; HPCA Position Paper on Euthanasia and Assisted Suicide 5.

59 Saunders Hospice and Palliative Care 106. 
terminally ill patient had a secondary effect in causing death. ${ }^{60}$ The practitioner acts in good faith if he or she uses normal medication in reasonable quantities, and the medication is administered with the object of relieving pain and not with the object of causing the death of the patient. ${ }^{61}$

It is submitted that, where the palliative caregiver acts in accordance with these guidelines, there will be no crime, for the criminal elements of unlawfulness and fault are absent. This means that the conduct of the palliative caregiver does not contravene the legal convictions of the community and that he or she did not have the required mens rea, as knowledge of unlawfulness was not present. Where a palliative caregiver is considering what will be the appropriate palliative treatment in particular circumstances, the following guidelines could serve as an aid to minimise the risk of unethical conduct and ultimately civil litigation. First, the caregiver should have a sound knowledge of the law on the issue in respect of which a decision needs to be made. ${ }^{62}$ To assist in interpreting the law, the caregiver should also know the applicable professional ethics and codes applicable to palliative care practitioners. ${ }^{63}$ Secondly, in making decisions regarding what effective palliative care plan to pursue, the palliative caregiver should be guided by four bio-ethical principles: respect for autonomy, beneficence, non-maleficence and justice. ${ }^{64}$ It is especially the respect for autonomy that underpins the concepts of informed consent, confidentiality and truth-telling about prognosis, treatment options and side-effects. ${ }^{65}$ In order to make informed decisions about their patients, palliative caregivers need to have a sound knowledge of the entire situation surrounding their patients and their desires or preferences. This allows palliative caregivers to make decisions with patients and their families based on all the facts available to them, and to avoid purely emotional decisions, dictated to by their own morals and ethics. $^{66}$

Also important to note is that palliative care has gone from a discipline associated with hospices providing relief from pain and suffering of cancerstricken patients and their families (especially during the end-of-life period) to a holistic and all-inclusive discipline, dealing with pain and death arising from HIV and other relevant diseases.

South Africa has now recognised the need to create equitable access to palliative care for a range of both communicable and non-communicable diseases and that it is no longer acceptable that only certain communities

60 Strauss Doctor, Patient and the Law 3ed (1993) 345; South African Law Commission Ibid.

62 Saunders Hospice and Palliative Care 115.

63 Ibid.

64 Gwyther Ethics and Palliative Care 2011 CME Continuing Medical Education.

65 Ibid.

66 Saunders Hospice and Palliative Care 116; also see HPCA www.hpca.co.za/pdf/ legalbook/HPCA\%20Chapter\%203\%20v6.pdf 30 in this regard.

67 National Policy Framework and Strategy on Palliative Care 2017-2022 https:///www.up.ac.za/media/shared/62/Palliative\%20Care\%20Resources/final-npfspcAugust-2017.ip166876.pdf. 
benefit from such care. ${ }^{68}$ The National Framework has as one of its main objectives the reaching out to all children and adults in need of palliative care. $^{69}$ The National Framework also recognises that such outreach can only be achieved if the focus is placed on strengthening services at primary healthcare level, which includes hospitals and clinics, as well as care within communities and in the homes of patients. ${ }^{70}$ The National Health Insurance Bill of $2019^{71}$ has as one of its goals the delivery of population-orientated primary healthcare services through the extensive use of community and home-based services in addition to primary healthcare. This includes community involvement and participation at community level. ${ }^{72}$ To understand the impact of the National Policy Framework and Strategy on Palliative Care, a brief discourse is necessary on what legislative steps, if any, South Africa has taken in order to give effect to the goals of the National Framework.

\section{Recommendations by the Hospice Palliative Care Association of South Africa}

The Hospice Palliative Care Association of South Africa (HPCA) is an Association incorporated under section 21 of the Companies $\mathrm{Act}^{73}$ and was founded in 1986 to address the needs of individual hospices and provincial associations to unify and advocate palliative care in South Africa and to provide effective, supportive care to communities in need. Members of the HPCA operate in more than 51 health districts and have more than 166 service sites. ${ }^{74}$ The Association opposes euthanasia and assisted suicide, but promotes palliative care for those experiencing pain and nearing the end of their life. ${ }^{75}$ The idea is to bring effective relief of pain and ease their dying. ${ }^{76}$

The HPCA advocates that access to effective and quality palliative care removes a patient's desire to be euthanised. The Association, besides calling for the integration of palliative care into the national healthcare system, encourages the improvement of skills development and the advancement of care planning and effective communication with end-of-life patients. $^{77}$

68 Wallis JA in Minister of Justice and Correctional Services v Estate Stransham-Ford supra par 100 cautioned: "The notion of a dignified death must be informed by a rounded view of society, not confined to a restricted section of it."

69 National Policy Framework and Strategy on Palliative Care https:///www.up.ac.za/media/ shared/62/Palliative\%20Care\%20Resources/final-npfspc-August-2017.ip166876.pdf.

70 Ibid.

71 Published in GG 42598 of 2019-07-26.

72 The Memorandum on the objectives of the National Health Insurance Bill, 201948.

71 of 2008.

74 Hospice and Palliative Care Association of South Africa (HPCA) www.ngopulse.ors/ organisation/hospice-palliative-care-association-southafrica (accessed 2019-08-04).

75 HPCA "Ethical Issues in Palliative Care" www.hpca.co.za/pdf/legalbook/ HPCA\%20Chapter\%203\%20v6.pdf 30.

76 HPCA Position Paper on Euthanasia and Assisted Suicide 5.

77 Ibid. 


\section{Recommendations of the South African Law Commission}

The South African Law Commission, after investigating the legitimacy of euthanasia in the South African context, drafted the End of Life Decisions Draft Bill in 1999. ${ }^{78}$ The Bill endorses an increase in the dosage of medication to a patient during palliative care, which may accelerate the death of the patient, provided that certain requirements are met. ${ }^{79}$

One can only assume that the Law Commission, when adopting section 4(1) of the End of Life Decisions Draft Bill, had in mind the danger for caregivers of criminal culpability in the form of dolus eventualis - that is, murder reasonably foreseen albeit with no direct intent. Through creating legislation of this nature, palliative caregivers who, for example, administer morphine or other similar drugs with the primary aim of suppressing pain and discomfort, knowing that those drugs have the potential to shorten patients' lives, will escape criminal prosecution once their actions are protected by law. It is suggested that the justification for section 4(1) of the Draft Bill can perhaps best be found in the fact that the palliative caregiver follows the precepts and ethics of his or her profession and prescribes a drug like morphine in a quantity merely sufficient to relieve pain. The object is clearly the relief of pain but there is also reasonable foreseeability that the patient's life may be shortened by taking the medication. Since the palliative caregiver acts within the legitimate context and sphere of his or her professional relationship with the patient, society consequently finds the palliative caregiver's conduct to be justified in accordance with its criteria of reasonableness and, therefore, not wrongful. Such a philosophical approach finds favour in other jurisdictions in the international arena, including the Netherlands and Canada.

\section{PALLIATIVE CARE AND PALLIATIVE SEDATION IN THE NETHERLANDS}

The Netherlands recognises both palliative care $^{80}$ and euthanasia ${ }^{81}$ as legitimate practices to assist those suffering from an incurable illness and

78 The End of Life Decisions Draft Bill 1999.

79 S 4 of the End of Life Decisions Draft Bill 1999 provides: "a medical practitioner may increase the dosage of medication to the patient, even if the secondary effect of such increase will be to shorten the life of the patient, subject to the following requirements: (a) it must be clear to the medical practitioner that the patient is suffering from a terminal illness; (b) it must also be clear to the medical practitioner that the patient's pain and distress cannot satisfactorily be alleviated by ordinary palliative treatment; (c) the medical practitioner must act in accordance with responsible medical practice with the object of relieving the patient's severe pain and distress; (d) the medical practitioner must not act with the intention to kill the patient."

80 De Rijksoverheid Voor Nederland "Levenseinde en Euthanasie" http://www.rijksoverheid.nl/ onderwerpen/levenseinde-en-euthanasie/ (accessed 2013-10-02).

81 Euthanasia is regulated by the Termination of Life on Request and Assisted Suicide (Review Procedures) Act (2001). 
who are in the final stages of their lives. ${ }^{82}$ Palliative care exists side by side with euthanasia but they are seen as two distinct practices. In the Netherlands, palliative care and specifically "palliative sedation" does not include euthanasia as provided for in terms of the Termination of Life on Request and Assisted Suicide Act. ${ }^{83}$ After all, the aims and objectives of introducing palliative care and palliative sedation practices have never been to kill the patient, but rather to bring relief to the patient's suffering. ${ }^{84}$ The Netherlands, unlike South Africa, does legally recognise that, even if certain drugs shorten human life, the palliative caregiver who administers the drug will not be criminally liable for his or her conduct. Sedative medication can thus be used legitimately to keep a terminally ill patient asleep until he or she dies. ${ }^{85}$ It is viewed as normal medical practice and not a form of euthanasia. ${ }^{86}$ It is often referred to as "double effect" medication as, on the one hand, it alleviates the patient's suffering but, on the other hand, it also hastens his or her death. ${ }^{87}$

\section{PALLIATIVE CARE AND PALLIATIVE SEDATION IN CANADA}

\section{General practice}

The practice of palliative care is very much embraced in Canada. It is said to be founded on the ethos of patient centredness, family focus and community-based treatment. Palliative care in Canada addresses not only the physical aspect of the patient, but also concentrates on the psychosocial dynamic and the spiritual needs of patients, their families and their support networks. ${ }^{88}$ The practice of palliative sedation is known in Canada almost along the same lines as in the Netherlands. ${ }^{89}$ Both the Canadian courts as well as the legislature recognise palliative sedation. The Supreme Court of British Columbia, in Carter $v$ Canada (Attorney-General), ${ }^{90}$ endorsed this practice when it found that "[p]hysicians may legally administer medications even though they know that the doses of medication in question may hasten death, so long as the intention is to provide palliative care by easing the patient's pain."

The Canadian authorities were serious about improving their palliative care system and, for that reason, the Parliamentary Committee on Palliative

\footnotetext{
82 De Rijksoverheid Voor Nederland http://www.rijksoverheid.nl/onderwerpen/levenseinde-eneuthanasie/.

83 Act 194 of 2001.

84 De Rijksoverheid http://www.rijksoverheid.nl/onderwerpen/levenseinde-en-euthanasie/.

85 De Rijksoverheid http://www.rijksoverheid.nl/onderwerpen/levenseinde-en-euthanasie/ palliatieve-sedatie.

86 Ibid.

Ibid.

88 Parliamentary Committee on Palliative and Compassionate Care "Not To Be Forgotten: Care of Vulnerable Canadians" November 201123.

89 See heading 4; Carter v Canada (Attorney-General) supra par 200.

90 Supra.

91 Par 231.
} 
and Compassionate Care was established in 2011 especially to bring about uniformity in improved palliative care in the entire Canada. ${ }^{92}$ Among its primary recommendations were the following: the development and implementation of a national strategy; the design and implementation of national standards as a benchmark of quality palliative care, ${ }^{93}$ the coordination and dissemination of palliative-care and end-of-life care research and information resources; ${ }^{94}$ continuous coordination and support of implementation of the national strategy; ${ }^{95}$ the development of a flexible and integrated model of palliative-care delivery, taking into account geographic, regional and cultural diversity in Canada; ${ }^{96}$ the provision of stable funding by government to palliative care $;^{97}$ the funding by government of a national public-awareness campaign on palliative care ${ }^{98}$ the strengthening by government of a home-care delivery programme that develops home-delivered palliative care resources in a manner that is sensitive to community, cultural, familial and spiritual needs; ${ }^{99}$ and the development of rural palliative-care delivery. ${ }^{10}$

South Africa urgently needs to pass legislation to create a strategic framework to bring about a uniform, sustainable and high-quality palliative system for its people. It would be well advised to borrow some of the recommendations of the Canadian Parliamentary Committee as referred to. In particular, South African needs to investigate palliative home care, involving community involvement in order to achieve meaningful coverage and care for terminally ill persons.

\section{Legislative framework introduced in Canada}

The Canadian government passed the Medical Assistance in Dying Bill on 17 June 2016. ${ }^{101}$ In terms of this Bill, medical assistance is available to eligible dying Canadians, which assistance also includes palliative care. With regard to palliative care, the Bill mainly provides that patients are required to be informed about what means are available to relieve their suffering, including palliative-care options, before they can continue with receiving assisted dying. This is to ensure that patients do not make rushed decisions

\footnotetext{
Parliamentary Committee on Palliative and Compassionate Care Not to be Forgotten: Care of Vulnerable Canadians 201115.

Ibid.

Ibid.

Ibid.

Ibid.

Ibid.

Ibid.

Ibid.

Ibid.

1 Government of Canada "An Act to Amend the Criminal Code and to Make Related Amendments to Other Acts (Medical Assistance in Dying)" https://lawslois.justice.gc.ca/eng/AnnualStatutes/2016_3/FullText.html (accessed 2020-08-13). See also Health Canada "Framework on Palliative Care in Canada" (December 2018) Canada.ca/en/health-canada/services/health-care-system/reports-publications/palliativecare/framework-palliative-care-canada.html.
} 
about their future based on misconceptions or misinformation. ${ }^{102}$ The Framework on Palliative Care in Canada Act ${ }^{103}$ was also passed shortly after the Medical Assistance in Dying Bill. ${ }^{104}$ The Act commits the Canadian Parliament to examine the state of palliative care in Canada within five years of the Act coming into operation, as well as for the Minister of Health to prepare a report on the state of palliative care and also present such report to Parliament.

It is evident from the aforegoing that the Canadian government is seriously committed to ensuring that palliative care is practised professionally and in the best interests of patients. This commitment is further evident in the fact that the Canadian government has rolled out palliative-care programmes in most of the states in Canada. ${ }^{106}$ What is significant about the development of its national framework is the inclusivity with which they approach their long-term strategy. Besides improving access to palliative care through inter alia hospitals and residential hospices, home care through community involvement is very much part of the strategy. Here, palliative training-and-education needs focus not only on healthcare providers, but also on caregivers from within their communities. ${ }^{107}$ It appears that Canadians have very much adopted a public-health approach to palliative care. It is an approach that originated in Australia and has since gained support on an international scale, including in Canada. ${ }^{108}$ All Canadian states have adopted the theory of practice that mobilises palliative care as a public-health issue in compassionate communities. Their ethos is built around the strong belief that in a compassionate community "it is everyone's responsibility to care for each other during times of crisis and loss, and not simply the task of the health professionals". Their cities and towns have adopted a charter (the so-called Compassionate City Charter) that serves as a tool to build compassionate communities, including schools, faith groups, institutions and businesses, and to drive the idea of community involvement in caring for those dying, and for families who are assisted in their grief after the passing of their loved ones. ${ }^{109}$ Many members of these communities are trained to assist in palliative care, especially in attending to the needs of people undergoing home care. Besides demystifying

102 See s $241.2(1)(e)$

103 S.C. (Statutes of Canada) 2017, c28; Health Canada https://www.canada.ca/ content/dam/hc-sc/documents/services/health-care-system/reports-publications/palliativecare/framework-palliative-care-canada/framework-palliative-care-canada.pdf.

104 Bill C-14 2016. This Bill intended to amend the Criminal Code to allow medical assistance to the dying.

105 S 4(1) of the Framework on Palliative Care in Canada Act S.C. (Statutes of Canada) 2017, c. 28.

106 Tompkins "Compassionate Communities in Canada: It Is Everyone's Responsibility" 2018 7(2) Annals of Palliative Medicine 2 apm.amegroups.com/article/view/19240/19358 (accessed 2018-07-08).

107 S 2(1) of the Framework on Palliative Care in Canada Act S.C. (Statutes of Canada) 2017, C. 282017.

108 Tompkins 2018 Annals of Palliative Medicine; Stoyles "It Takes a Village: Expert Calls for Community Involvement in Palliative Care" (18 August 2016) https:///www.australianageingagenda.com.au/2016/08/18/it-takes-a-village-expert-calls-forcommunity-involvement-in-palliative-care/.

109 Ibid. 
caregiving, death and dying, these trained individuals also provide moral support to those in crisis. ${ }^{10}$ Given the strong bond between Canada and South Africa in the post-apartheid era, it is suggested that Canada's innovative steps in palliative care need to be considered for adoption by the South African government. ${ }^{111}$

\section{THE PROPOSED WAY FORWARD FOR SOUTH AFRICA}

\section{General}

Although the South African Law Commission (now the South African Law Reform Commission) has proposed legislation in its Discussion Paper on Euthanasia and the Artificial Preservation of Life ${ }^{112}$ that would permit a medical practitioner to carry out a patient's request to die, the South African government has not reacted. The government also did not react to the Commission's End of Life Decisions Draft Bill 1999,, which provided for an increase in the allowable dosage of medication to a patient during palliative care, which increase may accelerate a patient's death. ${ }^{113}$ Seventeen years later, the Supreme Court of Appeal, in the case of Minister of Justice and Correctional Services $v$ Estate Stransham-Ford, ${ }^{114}$ refused to develop the common-law position with regard to murder relating to physicianadministered euthanasia and assisted suicide. At the same time, this particular case brought about more questions than answers. ${ }^{115}$ In the context of palliative-care practice, the consequences of administering the so-called double-effect medication, remains completely unsolved. Although the court seems to recognise that palliative care is an acceptable practice for alleviating the suffering of people in the final stages of a terminal illness, ${ }^{116}$ the court, did not give consideration to the acceleration of a person's death as result of administering double-effect medication.

The question therefore arises as to whether the current legal guidelines regulating palliative care in South Africa are not functioning as a proverbial straitjacket against the best interests of a palliative-care patient? On the one end of the spectrum is the patient's desire not to suffer for too long, while consenting to the increase in dosage of the medication has the effect of accelerating his or her death.

110 Ibid.

111 On the profound impact the Canadian law and jurisprudence has had on the understanding and application of rights, see Klug "The Canadian Charter, South Africa and the Paths of Constitutional Influence" (2017) https://www.cambridge.org/core/books/canada-in-theworld/canadian-charter-south-africa-and-the-paths-of-constitutional-influence/ 155C24B5103C13E4ABBA00760068AA60 (accessed 2019-06-09).

112 South African Law Commission Discussion Paper 71.

113 S 4(2) of the End of Life Decisions Draft Bill 1999.

114 Supra.

115 Par 101 of the judgment; Davidson "The Case for the Right to Dignity" (4 October 2018) https://www.dailymaverick.co.za/opinionista/2018-1004-sean-davidson-the-case-for-theright-to-die-with-dignity/.

116 Par 99 of the judgment. 
On the other end of the spectrum, the increase in dosage does present the aspect of euthanasia, which amounts to murder in the form of dolus eventualis inasfar as the palliative caregiver is concerned. ${ }^{117}$ This is the case despite the fact that an increase in dosage in order to relieve pain appears to be acceptable medical practice. However, is it fair to charge and convict a palliative caregiver with murder given the role that the patient plays in consenting to the caregiver's part in advancing death? However noble the palliative caregiver's conduct in these circumstances, his or her motive is clearly at odds with the South African common-law position. ${ }^{118}$

The influence of some of the rights enshrined in the Bill of Rights, inter alia those contained in sections $10,{ }^{119} 12^{120}$ and $15,{ }^{121}$ begs the question whether it is morally and judicially fair that the common-law situation should continue to prevail. Here, the issue of morality, patient autonomy or selfdetermination are important factors to be considered. What is at stake are the competing values of, on the one hand, the autonomy and dignity of a competent adult patient who seeks the acceleration of his or her death as a response to a grievous and irremediable medical condition, while, on the other hand, there is the value that the Supreme Court of Appeal in the Stransham-Ford case ${ }^{122}$ has placed on the right to life, which is rather unqualified. ${ }^{\text {T2 }}$

Patient autonomy is a well-known concept in South Africa, especially in cases involving medical treatment. ${ }^{124}$ Despite this, the Supreme Court of Appeal, in the Stransham-Ford case, refused to recognise that a defence of consent to a charge of murder may legally be raised, because the law has not reached a stage where the common law could be developed. ${ }^{125}$ The court held that the issue was not ventilated sufficiently in the court a quo. ${ }^{126}$ However, it is submitted that, when applied to a case of palliative care, a patient should have the right to consent to the administration of medication by a palliative caregiver to provide physical comfort, although it may accelerate his or her death. Such recognition would amplify and accentuate the dignity of the patient.

\footnotetext{
117 Saunders Hospice and Palliative Care 105; HPCA Position Paper on Euthanasia and Assisted Suicide 5.

118 For the common law position including mercy killing and active voluntary euthanasia see $S$ v Hartmann 1975 (3) SA 532 (C); S v De Bellocq 1975 (3) SA 538 (T) 539D; S v Marengo 1991 (2) SACR 43 (W) 47A-B; S v Smorenburg 1992 (2) SACR 389 (C).

119 The right to human dignity.

120 The right to the freedom and security of person, including the right to bodily and psychological integrity.

121 The right to freedom of conscience, religion, thought, belief and opinion.

122 Supra par 62, 63.

${ }^{123} \mathrm{~S} 11$ of the Constitution provides for the right to life.

124 See Minister of Justice and Correctional Services $v$ Estate Stransham-Ford supra with reference to Stoffberg $v$ Elliot 1923 CPD 148 par 31.

125 Minister of Justice and Correctional Services v Estate Stransham-Ford supra par 68

126 Par 74.
} 
Allowing a person to decide whether or not he wants to die shows recognition for his dignity and autonomy. ${ }^{127}$ It is accordingly submitted that, if a terminally ill patient cannot enjoy the quality of human life that he should, the law should provide for a palliative-care system that may keep the patient as comfortable as possible even though death is hastened. In this way, a patient is afforded the opportunity to die with dignity in the sense that his or her self-worth is not diminished.

Labuschagne submits that euthanasia and assisted suicide must be based on respect for human dignity and accompanying sympathy for other people who are suffering from an unbearable illness. ${ }^{128} \mathrm{He}$ further submits that the focus should be on the quality of life of the person who is enduring the suffering. ${ }^{129}$ It is submitted that palliative-care medication with a lifeshortening effect, of which both the palliative caregiver and the patient are aware and to which the patient has consented, should be viewed in the same way.

\section{Passing of legislation}

In our constitutional dispensation, one of the primary functions of the courts is to develop the common law in accordance with constitutional values. ${ }^{130}$ However, there are instances where it is better for the legislature to pass legislative enactments; the circumstances under which individuals could lawfully be assisted to end their lives may be such an instance. That is a position that is gaining increased support internationally. ${ }^{13}$

It is suggested that those tasked with developing legislation to regulate palliative care should have regard to regulations implemented by those countries whose socio-economic circumstances are similar to those of South Africa. Canada's model could also be an appropriate choice in that it has adopted a community-based palliative-care system, which reduces unnecessary costs. ${ }^{132}$ The Canadian system relies on compassionate communities to assist the national government in its quest to provide measurable high-quality palliative healthcare services to terminally ill

127 Bhamjee "Is the Right To Die With Dignity Constitutionally Guaranteed? Baxter v Montana and Other Developments in Patient Autonomy and Physician Assisted Suicide" 2010 31(2) Obiter 333352.

128 Labuschagne "Dekriminalisasie van Eutanasie" 1988 THRHR 167191.

129 Ibid.

$130 \mathrm{~S} 39(2)$ of the Constitution.

131 In the English decision, The Queen on the Application of Mrs Jane Nicklinson (in her own right and as Administratrix of Mr Tony Nicklinson Deceased) and Mr Paul Lamb v Minister of Justice and Director of Public Prosecutions and Her Majesty's Attorney-General (2013) EWCA Civ 961 (31 July 2013), the court stated at par 154-155: "if the law is to be changed, it must be changed by Parliament.... Parliament represents the conscience of the nation. Judges, however eminent, do not: our responsibility is to discover the relevant legal principles and apply the law as we find it." In the Stransham-Ford case supra par 73, the South African court expressed the view that because the issue of euthanasia raises complex questions of the public interest, the legislature was the "proper engine for legal development where regulations need to be created".

132 Tompkins apm.amegroups.com/article/view/19240/19356. 
persons and their families. ${ }^{133}$ As in Canada, the majority of people in South Africa value and care for infirm members within the family and broader community. ${ }^{134}$ India has also shown that local communities can be empowered to assist chronically ill and terminally ill persons and their families, despite limited resources. These communities are governed by the Ghandhian spirit "for the people, by the people, with the people". ${ }^{135}$ It is suggested that the South African government can also achieve this if it first, creates legislation that provides clarity, and avoids ambiguity, on the legal position of palliative care and euthanasia. Such legislation should respect constitutional values and be capable of being executed effectively and efficiently for the benefit of all who are affected by it. ${ }^{136}$

The mentioned values find expression in the Preamble and the Bill of Rights in the Constitution. The Preamble explicitly provides the constitutional imperative "to improve the quality of life for all citizens". ${ }^{137}$ Section $7(1)$ of the Constitution affirms that the Bill of Rights is "a cornerstone of democracy in South Africa" and "affirms the democratic values of human dignity, equality and freedom". The Constitution also places an overarching set of obligations on the State to "[r]espect, protect, promote and fulfil the rights in the Bill of Rights". ${ }^{138}$ One of those rights is the right of everyone to have access to healthcare services. ${ }^{139}$ This obligation places a duty on national and provincial government to adopt legislation and other measures to ensure equal access to healthcare facilities and provide high-quality medical services. This should include a national health policy framework on how to realise those rights. ${ }^{140}$ Home- and community-based care as a form of intervention in caring for the infirm and dying should rank highly when considering programmes to provide palliative care. This would include special training for health workers and volunteers who visit patients in their homes to provide appropriate care. Home- and community-based care would in turn free up hospital beds in instances where chronic-care patients have been hospitalised for lengthy periods. ${ }^{14}$

Section 27(2) of the Constitution also places an obligation on the State to "[t]ake reasonable legislative and other measures within its available resources, to achieve the progressive realisation of each of these rights". Accordingly, since 1994, this has received the attention of especially the Constitutional Court in the context of healthcare. The first case,

133 Ibid.

134 Minister of Justice and Correctional Services v Estate Stransham-Ford supra par 99.

135 Stjernsward "Community Participation in Palliative Care" 2005 11(1) IJPC 22-27 www.jpalliativecare.com/article.asp?issn=0973-1075 (accessed 2019-03-06).

136 The values included could consist of human dignity and Ubuntu. See Dawood $v$ Minister of Home Affairs 2000 (3) SA 936 (CC) par 35 on the application of human dignity; see further $S$ v Makwanyane 1995 (3) SA 391 (CC) par 224.

137 See the Preamble to the Constitution of the Republic of South Africa, 1996.

138 S 7(2) of the Constitution of the Republic of South Africa, 1996.

$139 \mathrm{~S} 27(1)(a)$ of the Constitution of the Republic of South Africa, 1996.

140 Heyns and Bekker "Introduction to the Rights Concerning Health Care in the South African Constitution" in Bekker (ed) A Compendium of Essential Documents on the Right to Health, Economic and Social Rights Series Vol 4.

141 Ibid. 
Soobramoney $v$ Minister of Health, KwaZulu-Natal, ${ }^{142}$ concerned the issue whether and under what circumstances limited resources constitute a valid basis for limiting access to medical treatment. In this case, Soobramoney insisted that he was entitled to healthcare in the form of dialysis treatment. The hospital refused this, as he was not an emergency patient. The hospital, at that stage, also lacked the required resources to help all patients with chronic kidney problems. The court held that the obligations imposed on the State regarding access to healthcare are dependent upon the resources available, as stated in sections 27(1) and 27(2). Because of limited resources, the hospital had adopted a policy of admitting only those patients who could be cured within a short period and those with chronic renal failure who were eligible for a kidney transplant. The court held that Soobramoney's demands were not reasonable, given the hospital's limited resources measured against the socio-historical context of South Africa. The court's decision has deservedly been criticised for its failure to develop the normative content of healthcare rights allied to the constitutional rights to life, dignity and healthcare.

The second case, Minister of Health $v$ Treatment Action Campaign: In re Certain Amicus Curiae Applications, ${ }^{143}$ concerned the government's policy not to make available Nevirapine to HIV-and-AIDS-related treatment on a larger scale. The court found the policy to be unconstitutional and unreasonable as the government had failed to take reasonable measures to provide access to healthcare to those in need. The important principle that flows from this case with regard to the fulfilment of the constitutionally protected right to health is that there must be a comprehensive programme, which may include a national framework. Legislative measures need to be put in place to promote the right of access to health services. In addition, a health programme is required that is directed at the progressive realisation of the right within its available resources. The legislative measures must be supported by appropriate, well-directed policies and programmes, and the programmes must respond to the needs of the most desperate. ${ }^{144}$

In the case of Minister of Health NO v New Clicks SA (Pty) Ltd (TAC Amici Curiae),${ }^{145}$ the Constitutional Court dealt with the regulation of fees for the dispensing of medicines by public and private pharmacies and how the regulations affect the right of access to healthcare services in terms of section 27(1)(a) and (2) of the Constitution. The court held that the right to healthcare services includes the right of access to medicine that is affordable. The court considered the measures that the State can take within its available resources to achieve the progressive realisation of that right but held that the State has an obligation to promote access to medicines that are affordable. ${ }^{146}$ The court subsequently held that a regulation of prices, to

1421998 (1) SA 765 (CC); 1997 (12) BCLR 1696 (CC).

1432002 (5) SA 713 (CC); 2002 (10) BCLR 1023; [2002] ZACC 13.

144 Moyo "Realising the Right to Health Care in South Africa" (2016) fhr.org.za/files/7215/1247/1732/Health.Pdf.

1452006 (2) SA 311 (CC); 2006 (1) BCLR 1; [2005] ZACC 14.

146 Par 514 
promote affordable medication, is wholly legitimate as a constitutional expression of its duties under section 27(2).

However, the principle of the progressive realisation of a right does not imply that the State can defer efforts for the full realisation of the right indefinitely. ${ }^{148}$ Healthcare, being one of the pillars of any concerned and caring society, deserves more. The advancement of this core entitlement to receive medical care, including palliative care, should be accelerated to comply with our commitment to international conventions "[t]o attain the highest standards of physical and mental health conducive to living a life of dignity". ${ }^{19}$ This is in alignment with the National Health Act, ${ }^{150}$ which, in its preamble, embraces socio-economic transformation in the healthcare system in order to improve the quality of life for all. ${ }^{151}$

The introduction of the proposed national health insurance legislation ${ }^{152}$ is seen by many as a saviour that will provide more equitable access to healthcare services in South Africa in future. However, even if the Bill is passed and becomes legislation in South Africa, the reality is that sustaining the scheme economically will present many challenges in the long run. A serious impact may be that additional healthcare professionals will be required to take up positions in hospitals and other healthcare centres. What exacerbates the situation is that inadequate workforce planning in the public domain has already had a major impact on the healthcare system. ${ }^{153}$

Given the limited resources at both national and provincial level, perhaps rolling out community and homecare services for palliative care for the dying is a desirable option. There should be an intensified thrust towards using more community-health workers and training them adequately. Adopting a more progressive resource-allocation policy will certainly move towards more sustainable and affordable health services for those in need of palliative care, thus taking South Africa a step closer to realising its constitutional duty to provide healthcare.

Allied to the above-mentioned reform measures, there is a need for the extensive promotion of public awareness of palliative care, and of the need for compassion and community involvement in assisting the dying and the grieving when the situation arises. However, community involvement will

147 Par 659

148 See International Commission of Jurists "The Limburg Principles on the implementation of the International Covenant of Economic, Social and Cultural Rights" in Economic, Social and Cultural Rights: A Compilation of Essential Documents (2005) 63 par 21.

149 See Article 12 of the International Covenant on Economic, Social and Cultural Rights (ICISCAR) 1976.

15061 of 2003.

151 The Preamble to the National Health Act 61 of 2003 recognises that we should "acknowledge the socio-economic injustices and inequalities of health services of the past, the need to establish a society based on social justice and foundational human rights, and the need to improve the quality of life for all in the country".

152 National Health Insurance Bill, 2019

153 Smith, Ranchod, Strugnell and Wishnia "Human Resources for Health Planning and National Health Insurance: The Urgency and the Opportunity (2018) SAHR 23 with reference to Veller "Public Health System in Dire Straits" (4 June 2018) https://www.pressreader.com/south-africa/cape-times/20180601/281861529185604. 
only succeed if some kind of mandatory community service can be developed.

It is further recommended that palliative care, for a certain period of time, should be integrated into the already-existing community service for medical graduates undergoing a compulsory period of postgraduate vocational training with appropriate supervision. Apart from medical graduates, it is also proposed that learners who are leaving school and who do not embark on a course in medicine, but have an interest in caring for ill people, should also be trained in palliative care and should also undergo compulsory community service for a period of approximately three months. It could be beneficial to our healthcare sector, in that interested parties may well pursue a career in medicine thereafter and, in so doing, transfer their skills into the labour market. This constitutes a third category of people who are capable of rendering voluntary palliative caregiving as part of a compassionate community drive to care for each other in times of crisis and loss. Providing assistance is seen, as Socrates once described it, as "the purpose of human life founded in personal and spiritual growth in a lived experience". ${ }^{154}$

The provision of such assistance can however only be achieved by way of a mission-oriented drive by national government to engage in public service and supported by urgently needed legislation. Encouraging community involvement in palliative care also falls squarely within the constitutional obligation of treating people who are in their final hour of need with the utmost compassion and dignity. In that way, the age-old spirit of Ubuntu, which encourages every member of the community to act in solidarity with those who find themselves in the most vulnerable state, plays a very important role.

\section{$7 \quad$ CONCLUSION}

Death is a natural phenomenon and an inescapable fact of life. While euthanasia remains unlawful in South Africa, there is only one alternative to mitigate symptoms, make life tolerable and ease emotional stress for dying people and their families: the concept of palliative care. To this end, this type of care has always been regarded as an ethically, morally and legally sound medical practice.

This article identifies palliative care as the only means of responding to end-of-life suffering. Furthermore, even if euthanasia were to be legalised in South Africa, palliative care and euthanasia can exist side by side in caring for the dying. On the basis that palliative care not only includes service to a patient, but also to family, friends and even the community where the patient is living, it can be said that it is Ubuntu-orientated. Ubuntu is an African practice that embraces values such as compassion, survival, respect and dignity. Therefore, Ubuntu has often been referred to and applied as a constitutional value.

154 Prinsloo "The Underlying Motives of University Student Volunteers Participating in Community Service Activities in Custodial Settings in South Africa: A Philosophical Perspective" 2016 17(2) Scielo www.scielo.org.za/scielo.php?script=sci_arttext\&pid=S1561 40182016000200009. 
This article hopes to further a greater understanding of the role communities can play in providing palliative care within neighbourhoods to serve the needs of terminally ill people at the end of life, as well as their families, suffering emotionally. It further strives to indicate how important it is for the South African government to adhere to the constitutional imperatives as stipulated in section 27 of the Bill of Rights. As already stated, society and local communities are caring entities and everything possible should be done in order to care for their members, ensuring inter alia that their healthcare needs are met. Anything else would be contrary to the true spirit of the Constitution. The adequate regulation of palliative care in South Africa by way of legislation is therefore of the utmost importance and should be a priority of government. 